\title{
The Use of Integrase InHibitors In TreatMent-experienced PATIENTS
}

\author{
Jose M. Gatell \\ Hospital Clínic, University of Barcelona, Barcelona, Spain
}

\begin{abstract}
Raltegravir, the first approved HIV-1 integrase inhibitor, is able to block the strand transfer step of the HIV proviral DNA integration process into the cellular host DNA. The selected dosage for the pivotal phase III studies (subsequently approved by the regulatory agencies) was $400 \mathrm{mg}$ bid by oral route with or without food. Raltegravir has a week effect (either inhibition or induction) on the hepatic cytochrone P450 activity. There is not need of dose adjustments in renal insufficiency or in mild-to-moderate hepatic impairment.

The emerging paradigm in the field of salvage therapy was to achieve a viral load below limit of detection in almost all patients. Pretty soon it became apparent that this was feasible in more than $70-90 \%$ of patients.

Raltegravir proved to be pivotal for this new paradigm. Raltegravir vs placebo both with an optimized background therapy has been tested for salvage therapy in the 005 and in the BENCHMRK studies (018 and 019). In all three studies proved to be superior to the placebo at 24, 48 and 96 weeks. Tolerance was remarkably good and virological failure was often associated with selection of integrase gene resistance mutations following the $\mathrm{Y} 143 \mathrm{C} / \mathrm{H} / \mathrm{R}, \mathrm{Q} 148 \mathrm{H} / \mathrm{K} / \mathrm{R}$ o less frequently the NI55H paths.

Finally, in the two SWITCHMRK studies non-inferiority vs Lopinavir/ $r$ could not be demonstrated in virogically suppressed patients with an stable cART containing Lopinavir/r. Most likely explanation was the presence of archived resistance mutationts to background therapy leading to a functional monotherapy with raltegravir.
\end{abstract}

\section{BACKGROUND}

The main objective of combined antiretroviral therapy (cART) is to fully and permanently suppress the Human Immunodeficiency Virus (HIV) replication and to achieve a plasma viral load (VL) level below the limit of detection by ultra- sensitive techniques (in general $<20-50$ copies of HIV RNA per ml of plasma) [1]. The immediate consequence is a self recovery of the immune system enough to dramatically reduce the incidence of new AIDS and non-AIDS associated events and the overall mortality [2]. This is feasible in almost $100 \%$ of naive patients complying with the prescribed medications. In the real world, however, the virologic failure rate at 48 weeks is about $5-10 \%$ and even higher when studies are prolonged up to 96144 weeks or longer [3]. The HIV is wild type in about $30-50 \%$ of failing patients (failures due to lack of adherence to the prescribed regimen). Resistance associated mutations (to one or more components of the cART) can be detected in the remaining 50-70\% of failing patients (less frequently when the initial regimen contains a ritonavir boosted protease inhibitor) [4]. The resistance profile after failure to first cART is relatively predictable and the response to a second line regimen is usually high even when resistance tests are not available and the salvage regimen are selected exclusively on the basis of best clinical judgment. Conversely, after two or more consecutive failing regimens most patients have accumulated a variety of resistance mutations (some of them only detectable under pharmacologic pressure if the usual bulk sequencing methodology is used) [5]. In these circumstances, and just a few years ago, response rate (measured as percentage of patients below 50 copies $/ \mathrm{ml}$ at 48 weeks) was very low $(<20-30 \%)$ even when the new optimized cART was guided by the results of resistance tests (genotypic or phenotypic). The main reason was not enough fully active drugs were available.

The "modern" era of salvage cART started with the introduction of enfuvirtide [6] (a new class of drugs without cross resistance to already existing classes) followed by tipranavir [7, 8], darunavir [9] and etravirine [10-13] (already existing classes but higher genetic barrier to resistance and only partial cross resistance to older members of the same class) and later on by raltegravir $[14,15]$, elvitegravir [16] (still in development) and maraviroc [17] (newer classes and no cross resistance with drugs of other classes). As a consequence, the emerging paradigm in the field of salvage therapy was to achieve a viral load below limit of detection in almost all patients [18]. Pretty soon it became apparent that this was feasible in more than 70 $90 \%$ of patients as long as: 1) at least 3 active drugs could be included in the optimized regimen [14, 15]; 2) the optimization was guided by the results of a resistance test (genotypic or phenotypic) and eventually by the co-receptors tropism determination when maraviroc was considered [19] and 3) the patient complied with the prescribed medications. Raltegravir proved to be pivotal for this new paradigm $[15,20]$. 


\section{RALTEGRAVIR}

Raltegravir (the first approved HIV-1 integrase inhibitor) [21] is able to block the strand transfer step of the HIV proviral DNA integration process into the cellular host DNA. The IC95 in human T lymphoid cell cultures is around $30 \mathrm{nmol}$ and its "potency" after 10 days of monotherapy in antiretroviral naïve patients is approximately $2 \log 10 \mathrm{HIV}-1$ RNA copies/ml of plasma. Rapidly absorbed after oral administration has a terminal half life of $7-12 \mathrm{~h}$ (being a potential qd drug). However, the selected dosage for the pivotal phase III studies (subsequently approved by the regulatory agencies) was $400 \mathrm{mg}$ bid by oral route with or without food. Studies testing qd administration are ongoing. Raltegravir is primarily metabolized by glucuronidation (UGT1A1 enzyme) with a weak effect (either inhibition or induction) on the hepatic cytochrone P450 activity [21]. There is no need of dose adjustments in renal insufficiency or in mild-to-moderate hepatic impairment [22]. No clinically relevant interactions have been reported between raltegravir and other antiretrovirals except a moderate increase in raltegravir concentrations $(25-95 \%$ depending on the parameter measured) when combined with atazanavir and somewhat less evident when atazanavir was boosted with ritonavir [21] . Rifampin substantially reduces the levels of raltegravir but with raltegravir doses of $400-800 \mathrm{mg}$ bid therapeutic levels may still be achievable [23].

\section{Raltegravir in Experienced Patients: SALVAGE THERAPY}

The 005 Phase II protocol was a multicentric randomized study including 179 patients with a plasma viral load above 5000 copies $/ \mathrm{ml}$ and resistance to at least one NRTI, one NNRTI and one PI [24] (Table 1).

Patients were assigned to an optimized background therapy (OBT) based on the results of the resistance tests plus raltegravir $(200,400$ or $600 \mathrm{mg}$ bid) or a placebo. The randomization was stratified by the concomitant utilization of atazanavir (that is able to increase the exposition to raltegravir) and also by the concomitant utilization of enfuvirtide. The main endpoint was the viral load drop at 24 weeks but at 16 weeks open label utilization raltegravir was allowed if virologic response was not detected. At 24 weeks the proportion of patients with a plasma viral load $<50$ copies $/ \mathrm{ml}$ was similar in the three raltegravir arms and ranged between $56 \%$ and $66 \%$ and was only $13 \%$ in the placebo arm. After week 24 the dose of raltegravir was $400 \mathrm{mg}$ bid in all patients on raltegravir (this is the dose selected for phase III studies on the basis of the 005 and other studies and subsequently approved by the regulatory authorities). There are plans to continue the study up to 144 weeks. The response rate $(<50$ copies $/ \mathrm{ml})$ for all pooled raltegravir arms at weeks 48 and 96 were $55 \%$ and $48 \%$ respectively (very similar to the $56-66 \%$ at 24 weeks) [25].

Most of the patients assigned to a raltegravir arm with lack of virologic response, or failure after responding, were receiving a functional monotherapy with raltegravir (none of the components of the OBT were fully active according to the resistance score). A genotypic resistance test could be performed in 38 of these patients of whom 35 selected resistance mutations in the integrase gene following the $\mathrm{N} 155 \mathrm{H}$ or the $\mathrm{Q} 148 \mathrm{H} / \mathrm{R} / \mathrm{K}$ path almost always associated with one additional mutation. The $\mathrm{N} 155 \mathrm{H}$ or the Q148H/R/K alone are associated with high or intermediate levels of resistance that became of very high level when additional mutations are selected [26]. Consequently, raltegravir is a very potent and durable drug but with a low-intermediate genetic barrier. Tolerance up to week 96 was very good (only 4\% discontinuations due to adverse events) and similar to the tolerance of placebo up to weeks 16-24 [25].

The BENCHMRK I and II studies (also known as 018 and 019 protocols) (Table 1) have been the pivotal phase III studies leading to raltegravir approval for salvage therapy $[27,28]$. Despite the main end-point was the percentage of patients below 400 copies $/ \mathrm{ml}$ at 16 weeks we now have data of the pooled analysis of both studies at 48 and 96 weeks measured as percentage of patients $<50$ copies $/ \mathrm{ml}$. There was a 2:1 randomization with 462 patients assigned to raltegravir (400 mg bid) and 237 to placebo. Inclusion criteria required a virological failure $(>1000$ copies $/ \mathrm{ml})$ and resistance to at least one member of the NRTI, NNRTI and PI families. Patients with stable coinfection with Hepatitis B and C were not excluded. All commercially available drugs were allowed in the optimized background including darunavir/ $\mathrm{r}$ or tipranavir/ $\mathrm{r}$ (both of them in expanded access or compassionate use at that moment).

In the pooled analysis (ITT, NC=F) at 48 weeks the response rate $(<50$ copies $/ \mathrm{ml})$ was $62 \%$ in the raltegravir and $33 \%$ in the placebo arm $(\mathrm{p}<0.001)$ (Fig 1). The response rates at 96 weeks were similar $(57 \%$ and $26 \%$ in the raltegravir and placebo arms respectively) [29]. CD4 response was also significantly better in the raltegravir arm (109 cells $/ \mu \mathrm{L}$ vs 45 cells $/ \mu \mathrm{L})$. Side effects potentially related with study medication were rare and similar in both arms with less than 1\% interruptions due to intolerance in both arms (around 3 per 100 person-years). Cancer events were below what could be expected in the general population.

The superiority of raltegravir vs placebo was still significant after adjusting for the baseline characteristics of the patients (demographic, viral load, CD4+ $\mathrm{T}$ cell count and genotypic and phenotypic score). Of note, near $50 \%$ of the raltegravir patients vs almost none $(3 \%)$ of the placebo recipients were below 50 copies $/ \mathrm{ml}$ at 48 weeks despite a baseline resistance (genotypic or phenotipic score) of zero (functional monotherapy with raltegravir), suggesting both that the genetic barrier of raltegravir is not so low and that some components of the OBT retained some level of activity despite a theoretical score of zero. Conversely, when the OBT contains two or event more active drugs the raltegravir still contributes with additional activity (70\% response vs $40-60 \%$ respectively). Moreover, the response rate is near $90 \%$ when raltegravir was used with darunavir/ $\mathrm{r}$ and enfuvirtide in patients never exposed to these drugs (Fig. 2). Overall, by week 96 resistance tests were available for 112 raltegravir treated patients of whom $73 \%$ had integrase muta- 
Table 1. Clinical studies of raltegravir (RAL).

\begin{tabular}{|c|c|c|c|c|c|}
\hline Study & Phase & $\begin{array}{l}\text { No. of } \\
\text { participants }\end{array}$ & Study population & Study Regimen & Results \\
\hline \multicolumn{6}{|l|}{005 [25] } \\
\hline Main & II & 178 & $\begin{array}{l}\text { HIV-infected, treatment- } \\
\text { experienced; HIV RNA } \\
\text { level }>5000 \text { copies } / \mathrm{mL} \text {; } \\
\text { CD4cell count }>50 \\
\text { cells } / \mu \mathrm{L}\end{array}$ & $\begin{array}{l}\text { OBT and RAL ( } 200, \\
400 \text {, or } 600 \mathrm{mg}) \text { or } \\
\text { placebo twice daily }\end{array}$ & $\begin{array}{l}\text { At week } 24 \text {, the propor- } \\
\text { tions of patients with an } \\
\text { HIV-1 RNA level } \\
<50 \text { copies } / \mathrm{mL} \text { were } 65 \% \\
\text { (RAL; } 200 \mathrm{mg}), 56 \% \text { (RAL; } \\
400 \mathrm{mg}), 67 \% \text { (RAL; } 600 \mathrm{mg} \text { ), } \\
\text { and } 13 \% \text { (placebo) }\end{array}$ \\
\hline Extension & II & 178 & Same as above & $\begin{array}{l}\text { OBT and RAL } \\
\text { ( } 400 \mathrm{mg} \text {; beginning at } \\
\text { week 24) or placebo } \\
\text { twice daily }\end{array}$ & $\begin{array}{l}\text { At week } 48 \text {, the propor- } \\
\text { tions of patients with an } \\
\text { HIV-1 RNA level } \\
<50 \text { copies } / \mathrm{mL} \text { were } 64 \% \\
\text { (RAL; } 200 \mathrm{mg}), 46 \% \text { (RAL; } \\
400 \mathrm{mg}), 53 \% \text { (RAL; 600mg), } \\
\text { and } 9 \% \text { (placebo) }\end{array}$ \\
\hline \multicolumn{6}{|l|}{ BENCHMRK $[14,38]$} \\
\hline Trial 018 & III & 350 & $\begin{array}{l}\text { HIV-1-infected, treat- } \\
\text { ment-experienced; HIV } \\
\text { RNA level >1000 } \\
\text { copies/mL; CD4cell } \\
\text { count }\end{array}$ & $\begin{array}{l}\text { OBT and RAL } \\
\text { ( } 400 \mathrm{mg} \text { ) or placebo } \\
\text { twice daily (random- } \\
\text { ized } 2: 1 \text { ) }\end{array}$ & $\begin{array}{l}\text { At week } 48 \text {, the propor- } \\
\text { tions of patients with an } \\
\text { HIV RNA level } \\
<50 \text { copies } / \mathrm{mL} \text { were } \\
65 \% \text { (RAL), and } 31 \% \\
\text { (placebo) }\end{array}$ \\
\hline Trial 019 & III & 349 & Same as above & Same as above & $\begin{array}{l}\text { At week } 48 \text {, the propor- } \\
\text { tions of patients with an } \\
\text { HIV-1 RNA level } \\
<50 \text { copies } / \mathrm{mL} \text { were } \\
60 \%(\mathrm{RAL}) \text {, and } 35 \% \\
\text { (placebo) }\end{array}$ \\
\hline \multicolumn{6}{|l|}{ SWITCHMRK [34] } \\
\hline 032 & III & 348 & $\begin{array}{l}\text { Well controlled }(<50 \\
\text { copies } / \mathrm{ml} \text { for } \geq 3 \mathrm{mo} \text {.) } \\
\text { on a stable lopinavir } / \mathrm{r} \\
\text { regimen in combination } \\
\text { with at least } 2 \text { nucleo- } \\
\text { sides }\end{array}$ & $\begin{array}{l}\text { Continue or switch } \\
\text { from lopinavir/r to } \\
\text { raltegravir }\end{array}$ & $\begin{array}{l}\text { At week } 24 \text { proportion of } \\
\text { patients remaining }<50 \\
\text { copies } / \mathrm{ml} \text { were } 87 \% \text { in } \\
\text { lopinavir } / \mathrm{r} \text { vs. } 81 \% \text { in ralte- } \\
\text { gravir arm }\end{array}$ \\
\hline 033 & III & 354 & same & same & $\begin{array}{l}\text { At week } 24 \text { proportion of } \\
\text { patients remaining }<50 \\
\text { copies } / \mathrm{ml} \text { were } 94 \% \text { in } \\
\text { lopinavir/r vs. } 88 \% \text { in ralte- } \\
\text { gravir arm }\end{array}$ \\
\hline TRIO (ANRS139) [30] & IV & 103 & $\begin{array}{l}\text { Failing patients with VL } \\
>1000 \text { copies / ml, naive } \\
\text { and sensitive to study } \\
\text { drugs }\end{array}$ & $\begin{array}{l}\text { Raltegravir }+ \\
\text { Darunavir } / \mathrm{r}+ \\
\text { Etravirine }\end{array}$ & $\begin{array}{l}\text { At week } 48,89 \% \text { below } 50 \\
\text { copies } / \mathrm{ml}\end{array}$ \\
\hline
\end{tabular}

tions at one of the three positions $(\mathrm{Y} 143 \mathrm{C} / \mathrm{H} / \mathrm{R}$, $\mathrm{Q} 148 \mathrm{H} / \mathrm{K} / \mathrm{R} \mathrm{N} 155 \mathrm{H}$ ) almost always in combination with at least one other mutation. Most resistance mutations were observed by week 24 and in only 7 cases after week 48 [29].

The French TRIO trial (ANRS139) further reinforces that a high level response rate is achievable in salvage therapy when 3 fully active drugs are included in the regimen. They included 103 failing patients (VL>1000 copies/ml) naïve to raltegravir, darunavir/r and etravirine and susceptible to these drugs. They received a cART with these three drugs and the response rate $(<50$ copies $/ \mathrm{ml})$ was $90 \%$ at 24 weeks and $86 \%$ at 48 weeks [30]. These results were duplicated in a smaller (32 patients) but similar trial with a response rate of $94 \%(<50$ copies $/ \mathrm{ml})$ at 24 weeks [31]. 


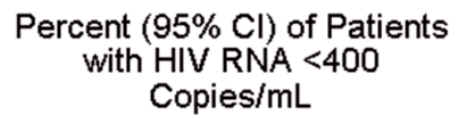

Percent $(95 \% \mathrm{Cl})$ of Patients with HIV RNA $<50$ Copies $/ \mathrm{mL}$
Mean Change from Baseline $(95 \% \mathrm{Cl})$ in CD4 Cell Count
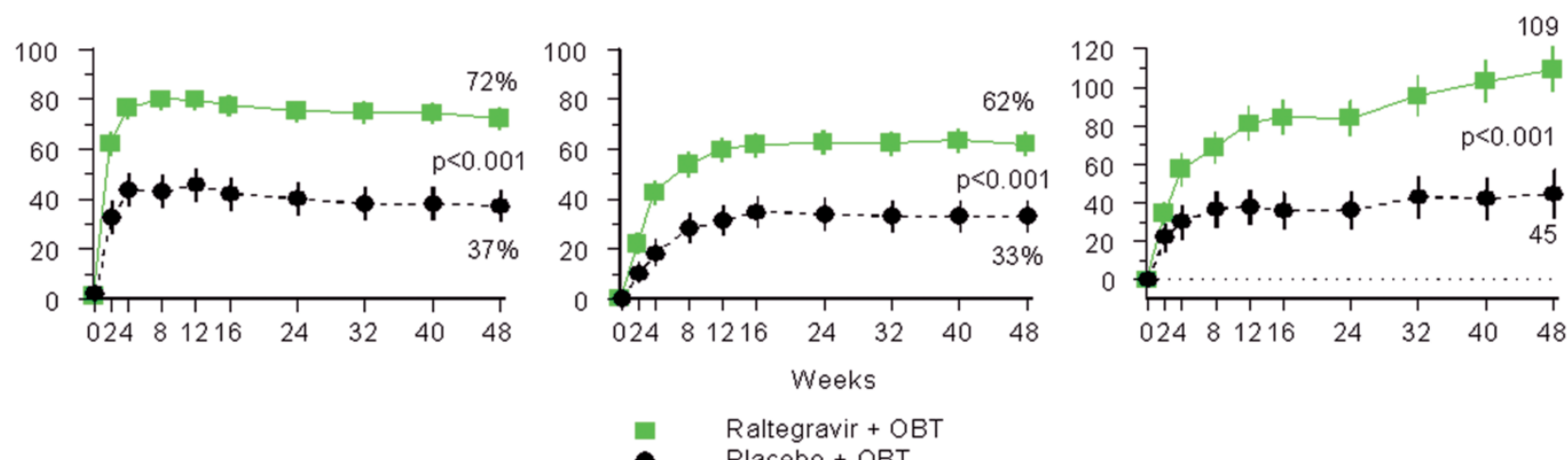

For HIV RNA $<400$ copies $/ \mathrm{mL}$ and $<50$ copies $/ \mathrm{mL}$ : Non-completer $=$ failure approach. For CD4: Baseline carried forward for virologic failures.

Fig 1. Virologic and CD4 outcome in the pooled BENCHMRK studies at 48 weeks $[14,29,38]$.

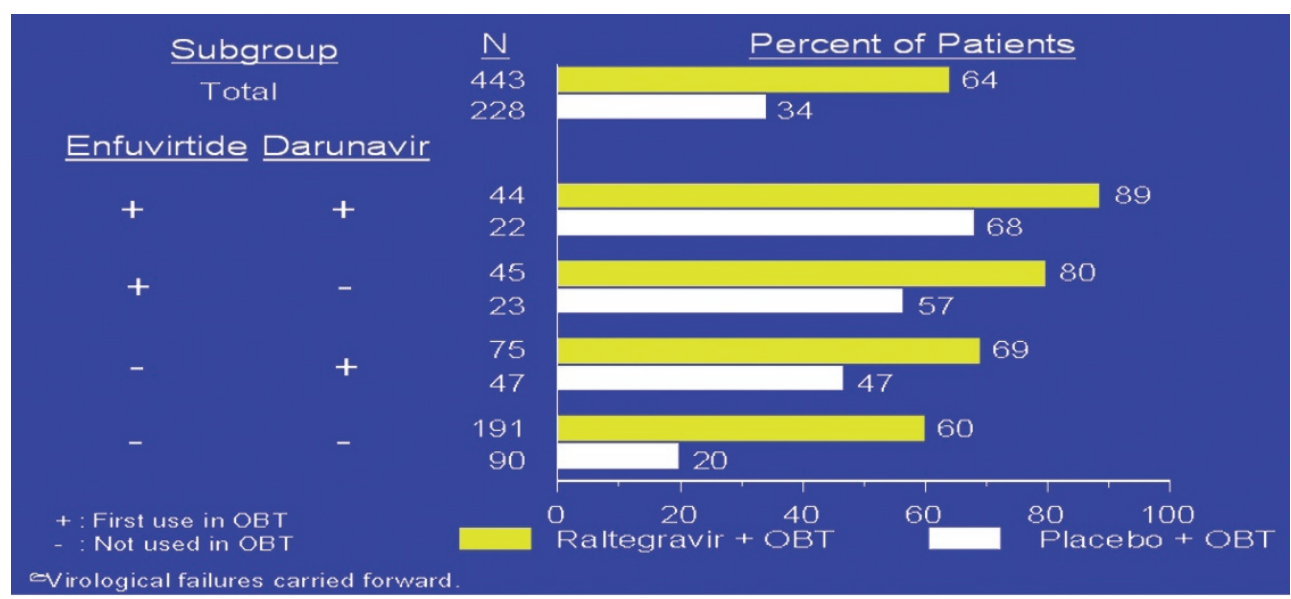

Fig 2. Virologic outcome in the BENCMRK studies stratifying by previously exposure to Darunavir/ Ritonavir and Enfuvirtide. Nothe a near $90 \%$ response rate among first time users of Raltegravir, Darunavir/Ritonavir and Enfuvirtide [14, 29, 38].

\section{RAltegravir in EXPERIENCED PATIENTS: Switching STUdiES IN Virologically Suppressed Patients}

In virologically suppressed patients switching from enfuvirtide to raltegravir has been tested in at least one randomized study and in two open studies. In the French randomized EASIER study (ANRS138) 85 patients were assigned to continue with enfuvirtide and 85 patients to switch from enfuvirtide to raltegravir while the remaining drugs were maintained. In both arms at 24 weeks near $90 \%$ of the patients had a plasma viral load below 50 copies $/ \mathrm{ml}$. At this time point the patients on enfuvirtude were switched to raltegravir. At 48 weeks again near $90 \%$ patients in both arms remained below 50 copies/ml of plasma. Similar results were obtained in two open lable studies including 52 and 35 patients respectively [32, 33]. Consequently, the option of switching from enfuvirtide to raltegravir in suppressed patients never exposed to raltegravir con be accepted as an effective and safe alternative.

The SWITCHMRK studies 1 and 2 (Protocols 032 and 033) included 702 virologicaly suppressed pa- tients randomized to continue on lopinavir/ $\mathrm{r}$ containing regimen or to switch from lopinavir/ $\mathrm{r}$ to raltegravir. The co-primary end points were lipid changes at week 12, virologic response at week 24 (non-inferiority hypothesis with 12\% margin) and safety and tolerability. While lipid changes were significantly better in the experimental raltegravir arm none of the two studies were able to demonstrate non-inferiority of the raltegravir arm $(87 \%$ vs $81 \%$ in the 032 protocol and $94 \%$ vs $88 \%$ in the 033 protocol; lower limit of the $95 \%$ CI of $-14,4$ and $-12,2$ respectively. Both studies were interrupted by the DSMB [34]. Most likely explanation for the excess of virological failures in the raltegravir arms were presence of archived mutations to the background antiretrovirals due to previous virological failures and consequently these patients were exposed to functional raltegravir monotherapy. Once again the SWITCHMRK studies underlined the relatively low genetic barrier of raltegravir as compared with a ritonavir boosted protease inhibitor like lopinavir/r. The possibility of switching from ritonavir boosted PI to raltegravir is probably save as long as the patients have not archived resistance mutations to the background drugs and this hy- 
pothesis is being tested in the Spanish SPIRAL switch study.

\section{Raltegravir in Experienced Patients: INTENSIFICATION STUDIES}

The possibility of eradicating the HIV-1 in virologicaly suppressed patients $(<50$ copies $/ \mathrm{ml})$ intensifying the regimen by adding raltegravir or alternatively efavirenz, lopinavir/r or atazanavir/ were not able to reduce the residual viremia when an ultra sensitive single-copy assay was used $[35,36]$. This data are in favor of the hypothesis that residual viremia is not due to ongoing level replication as opposed to cellular release (by latently infected cells) of replicative competent viral particles [37].

\section{REFERENCES}

1. Hammer SM, Eron JJ, Jr., Reiss P, Schooley RT, Thompson MA, Walmsley S, et al. Antiretroviral treatment of adult HIV infection: 2008 recommendations of the International AIDS Society-USA panel. JAMA 2008; 300(5): 555-570.

2. Palella FJ, Delaney KM, Moorman AC, Loveless MO, Fuhrer J, Satten GA, et al. Declining morbidity and mortality among patients with advanced human immunodeficiency virus infection. N Engl J Med 1998; 338, 853-860.

3. Arribas JR, Pozniak AL, Gallant JE, DeJesus E, Gazzard B, Campo RE, et al. Tenofovir Disoproxil Fumarate, Emtricitabine, and Efavirenz Compared With Zidovudine/Lamivudine and Efavirenz in Treatment-Naive Patients: 144-Week Analysis. J Acquir Immune Defic Syndr 2008; 47(1):74-78.

4. Gupta R, Hill A, Sawyer AW, Pillay D. Emergence of drug resistance in HIV type 1 -infected patients after receipt of first-line highly active antiretroviral therapy: a systematic review of clinical trials. Clin Infect Dis 2008; 47(5):712-722.

5. Hirsch MS, Gunthard HF, Schapiro JM, Brun-Vezinet F, Clotet B, Hammer SM, et al. Antiretroviral drug resistance testing in adult HIV-1 infection: 2008 recommendations of an International AIDS Society-USA. Clin Infect Dis. In press 2008.

6. Lazzarin A, Clotet B, Cooper D, Reynes J, Arasteh K, Nelson M, et al. Efficacy of enfuvirtide in patients infected with drug-resistant HIV-1 in Europe and Australia. N Engl J Med 2003; 348(22):2186-2195

7. Temesgen Z, Feinberg J. Tipranavir: a new option for the treatment of drug-resistant HIV infection. Clin Infect Dis 2007; 45(6):761-769.

8. Hicks CB, Cahn P, Cooper DA, Walmsley SL, Katlama C, Clotet B, et al. Durable efficacy of tipranavir-ritonavir in combination with an optimised background regimen of antiretroviral drugs for treatment-experienced HIV-1-infected patients at 48 weeks in the Randomized Evaluation of Strategic Intervention in multi-drug reSistant patients with Tipranavir (RESIST) studies: an analysis of combined data from two randomised open-label trials. Lancet 2006; 368(9534):466-475.

9. Clotet B, Bellos N, Molina JM, Cooper D, Goffard JC, Lazzarin A. et al. Efficacy and safety of darunavir-ritonavir at week 48 in treatment-experienced patients with HIV-1 infection in POWER 1 and 2: a pooled subgroup analysis of data from two randomised trials. Lancet 2007; 369(9568):1169-1178.

10. Lazzarin A, Campbell T, Clotet B, Johnson M, Katlama C, Moll A, et al. Efficacy and safety of TMC125 (etravirine) in treatment-experienced HIV-1-infected patients in DUET-2: 24-week results from a randomised, doubleblind, placebo-controlled trial. Lancet 2007; 370(9581): $39-48$.

11. Madruga JV, Cahn P, Grinsztejn B, Haubrich R, Lalezari J, Mills A et al. Efficacy and safety of TMC125 (etravirine) in treatment-experienced HIV-1-infected patients in DUET-1: 24-week results from a randomised, double-blind, placebo-controlled trial. Lancet 2007; 370 (9581):29-38.

12. Cohen CJ, Berger DS, Blick G, Grossman HA, Jayaweera DT, Shalit P et al. Efficacy and safety of etravirine (TMC125) in treatment-experienced HIV-1-infected patients: 48-week results of a phase IIb trial. AIDS 2008.

13. Haubrich R, Cahn P, Grinsztein B, Lalezari J, Madruga J, Mills A. et al. DUET-1: week-48 results of a phase III randomized double-blind trial to evaluate the efficacy and safety of TMC125 vs placebo in 612 treatment-experienced HIV-1-infected patients. 15th Conference on Retroviruses and Opportunistic Infections . 2008.

14. Steigbigel RT, Cooper DA, Kumar PN, Eron JE, Schechter M, Markowitz M, et al. Raltegravir with optimized background therapy for resistant HIV-1 infection. N Engl J Med 2008; 359(4):339-354.

15. Cooper DA, Steigbigel RT, Gatell JM, Rockstroh JK, Katlama C, Yeni P, et al. Subgroup and resistance analyses of raltegravir for resistant HIV-1 infection. N Engl J Med 2008; 359(4):355-365.

16. Roquebert B, Damond F, Collin G, Matheron S, Peytavin $G$, Benard A, et al. HIV-2 integrase gene polymorphism and phenotypic susceptibility of HIV-2 clinical isolates to the integrase inhibitors raltegravir and elvitegravir in vitro. J Antimicrob Chemother 2008.

17. Gulick RM, Lalezari J, Goodrich J, Clumeck N, DeJesus E, HORBAN A, et al. Maraviroc for previously treated patients with R5 HIV-1 infection. N Engl J Med 2008; 359(14):1429-1441.

18. Hammer SM, Eron JJ, Jr., Reiss P, Schooley RT, THOMPSON MA, Walmsley S, et al. Antiretroviral treatment of adult HIV infection: 2008 recommendations of the International AIDS Society-USA panel. JAMA 2008; 300(5):555-570.

19. Saag M, Goodrich J, Fatkenheuer G, Clotet B, Clumeck $\mathrm{N}$, Sullivan J, et al. A double-blind, placebo-controlled trial of maraviroc in treatment-experienced patients infected with non-R5 HIV-1. J Infect Dis 2009; 199(11):1638-1647.

20. Steigbigel RT, Cooper DA, Kumar PN, Eron JE, Schechter M, Markowitz M, et al. Raltegravir with optimized background therapy for resistant HIV-1 infection. N Engl J Med 2008; 359(4):339-354.

21. Hicks C, Gulick RM. Raltegravir: The First HIV Type 1 Integrase Inhibitor. Clin Infect Dis 2009.

22. Iwamoto M, Hanley WD, Petry AS, Friedman EJ, Kost JT, Breidinger SA, et al. Lack of a Clinically Important Effect of Moderate Hepatic Insufficiency and Severe Renal Insufficiency on Raltegravir Pharmacokinetics. Antimicrob Agents Chemother 2009.

23. Wenning LA, Hanley WD, Brainard DM, Petry AS, Ghosh K, Jin B, et al. Effect of Rifampin, a Potent Inducer of Drug Metabolizing Enzymes, on the Pharmacokinetics of Raltegravir. Antimicrob Agents Chemother 2009.

24. Grinsztejn B, Nguyen BY, Katlama C, Gatell JM, Lazzarin A, Vittecoq D, et al. Safety and efficacy of the HIV1 integrase inhibitor raltegravir (MK-0518) in treatmentexperienced patients with multidrug-resistant virus: a phase II randomised controlled trial. Lancet 2007; 369(9569):1261-1269.

25. Gatell JM, Katlama C, Grinsztejn B, Eron JJ, Lazzarin A, Vittecoq D, et al. Long-term efficacy and safety of the HIV integrase inhibitor raltegravir in patients with limited treatment options in a phase II study. J Acquir Immune Defic Syndr 2009; (in press). 
26. Grinsztejn B, Nguyen BY, Katlama C, Gatell JM, Lazzarin A, Vittecoq D, et al. Safety and efficacy of the HIV-1 integrase inhibitor raltegravir (MK-0518) in treatment-experienced patients with multidrug-resistant virus: a phase II randomised controlled trial. Lancet 369, 1261-1269. 2007.

27. Steigbigel RT, Cooper DA, Kumar PN, Eron JE, Schechter M, Markowitz M, et al. Raltegravir with optimized background therapy for resistant HIV-1 infection. N Engl J Med 2008; 359(4):339-354.

28. Cooper DA, Steigbigel RT, Gatell JM, Rockstroh JK, Katlama C, Yeni P, et al. Subgroup and resistance analyses of raltegravir for resistant HIV-1 infection. N Engl J Med 359, 355-365. 2008.

29. Steigbigel R, Cooper DA, Teppler H, Eron JJ, Gatell JM, Kumar PN, et al. Long-term efficacy and safety of raltegravir combined with optimized background therapy in treatment-experienced patients with resistant HIV infection: Week 96 results of the BENCHMRK 1 and 2 phase III trials. Clin Infect Dis 2009; (in press).

30. Fagard C, Descamps D, Dubar V, Colin C, Taburet AM, Roquebert B. Efficacy and safety of raltegravir plus etravirine and darunavir/ritonavir in treatment experienced patients with multidrug resistant virus: 48 weeks results from the ARNS 139 TRIO trial. 5th IAS.Cape Town.July 19-22 . 2009.

31. Imaz A, Del Saz SV, Ribas MA, Curran A, Caballero E, Falco V, et al. Raltegravir, Etravirine, and RitonavirBoosted Darunavir: A Safe and Successful Rescue Regimen for Multidrug-Resistant HIV-1 Infection. J Acquir Immune Defic Syndr 2009.

32. Harris M, Larsen G, Montaner JS. Outcomes of multidrug-resistant patients switched from enfuvirtide to raltegravir within a virologically suppressive regimen. AIDS 2008; 22(10):1224-1226.

33. Towner W, Klein D, Kerrigan HL, Follansbee S, Yu K, Horberg M. Virologic outcomes of changing enfuvirtide to raltegravir in HIV-1 patients well controlled on an enfuvirtide based regimen: 24-week results of the CHEER study. J Acquir Immune Defic Syndr 2009; 51(4):367-373.
34. Eron J, Andrade JMJ, Zajdenverg R, Workman J, Cooper D, Young B. Switching from stable lopinavir/ritonavir based to raltegravir based combination antiretroviral therapy resulted in superior lipid profile at week 12 but did not demonstrate non-inferior efficacy at week 24. 16th Conference on Retrovirus Opportunistic Infections. Montreal, February 2009.

35. Dinoso JB, Kim SY, Wiegand AM, Palmer SE, Gange SJ, Cranmer L, et al. Treatment intensification does not reduce residual HIV-1 viremia in patients on highly active antiretroviral therapy. Proc Natl Acad Sci U S A 2009; 106(23):9403-9408.

36. Dinoso JB, Jones J, McMahon D. Antiretroviral intensification does not reduce persistent HIV viremia on therapy. XIII International Drug Resistance Workshop.Fort Myers,Florida . 2009.

37. Bailey JR, Sedaghat AR, Kieffer T, Brennan T, Lee PK, Wind-Rotolo M, et al. Residual human immunodeficiency virus type 1 viremia in some patients on antiretroviral therapy is dominated by a small number of invariant clones rarely found in circulating CD4+ T cells. J Virol 2006; 80(13):6441-6457.

38. Cooper DA, Steigbigel RT, Gatell JM, Rockstroh JK, Katlama C, Yeni P, et al. Subgroup and resistance analyses of raltegravir for resistant HIV-1 infection. N Engl J Med 2008; 359(4):355-365.

Address for correspondence:

Jose M. Gatell MD, PhD

Hospital Clínic

University of Barcelona

Villarroel 170

08036 Barcelona

Spain

E-mail: gatell0@attglobal.net 